\title{
TINJAUAN YURIDIS INFORMED CONSENT DALAM PERLINDUNGAN HUKUM BAGI PASIEN DAN DOKTER
}

\author{
I Gede Made Wirabrata (1), I Made Wirya Darma (2) \\ wira.brata@yahoo.com ${ }^{(1)}$,dedukdd81@gmail.com ${ }^{(2)}$
}

\section{Undiknas Graduate School}

\begin{abstract}
Research conclusions, namely: legal protection for the patient and the doctor there has been legislation that set it up, but not completely able to accommodate all aspects of legal protection needs. Informed consent is written consent from the patient/family nearby over the actions will be undertaken by medical doctor/dentist. The Alliance between the patient and the doctor was done with purpose either. Legal protection for patients (although there have been informed consent), the doctor can be sued in the civil code, if the malpractice due to negligence, with indemnities. A doctor/dentist may was penalized by the patient over the action of Medicine/Dentistry which give rise to the condition of the patient in question the heavy injuries worse or even died, due to complaints of the patient/family. Medical action carried out by a doctor to his patient, occurs negligent or malpractice deaths, may be subject to criminal sanctions. Research suggestions, namely: the need to perform the addition of clause rules of informed consent, either in the form of article or paragraph, so that the overall needs for legal protection for the patient and the doctor can be met. Improved education for the patient/family about the benefits of informed consent for him to legally protect against medical action. Increased understanding of informed consent for doctors/dentists, that it is very useful in protecting himself from a lawsuit that could possibly occur in the medical action.
\end{abstract}

Keywords: informed consent, civil law, criminal law, medical action

\begin{abstract}
ABSTRAK
Perlindungan hukum bagi pasien dan dokter telah ada perundangundangan yang mengaturnya, namun belum sepenuhnya dapat mengakomodir semua kebutuhan aspek perlindungan hukum. Informed consent adalah persetujuan tertulis dari pasien/keluarga terdekat atas tindakan kedokteran yang akan dilakukan oleh dokter/dokter gigi. Perikatan antara pasien dan dokter dilakukan dengan itikat baik. Perlindungan hukum bagi pasien (walaupun telah ada informed consent), dokter dapat digugat secara perdata, jika terdapat malpraktik akibat kelalaian, dengan penggantian kerugian. Seorang dokter/dokter gigi dapat dipidanakan oleh pasien atas tindakan kedokteran/kedokteran gigi yang menimbulkan kondisi pasien yang bersangkutan lebih buruk atau luka berat bahkan meninggal, dengan adanya pengaduan dari pasien/keluarganya. Tindakan kedokteran yang dilakukan oleh dokter kepada pasiennya, terjadi kematian akibat kealpaannya atau malpraktik, dapat dikenai sanksi pidana. Saran penelitian, yaitu: Perlunya melakukan penambahan klausul aturan informed consent, baik dalam bentuk pasal atau ayat, agar secara menyeluruh kebutuhan akan perlindungan hukum bagi pasien dan dokter dapat dipenuhi. Peningkatan edukasi bagi pasien/keluarganya tentang manfaat informed consent bagi dirinya untuk melindungi secara hukum terhadap tindakan kedokteran. Peningkatan pemahaman informed consent bagi
\end{abstract}


dokter/dokter gigi, bahwa hal ini sangat berguna dalam melindungi dirinya dari gugatan hukum yang mungkin dapat terjadi dalam melakukan tindakan kedokteran. Perikatan yang terjadi dalam bentuk informed consent antara pasien dan dokter harus dilakukan dengan itikat baik dari kedua belah pihak. Sanksi pidana atas malpraktik tindakan kedokteran perlu ditinjau nominal denda sesuai dengan kondisi nilai tukar mata uang negara Indonesia saat ini.

Kata Kunci: informed consent, hukum perdata, hukum pidana, tindakan kedokteran

\section{PENDAHULUAN}

Sesuai dengan amanat Undang-undang Dasar 1945 Pasal 28 H, bahwa Setiap orang berhak hidup sejahtera lahir dan batin, bertempat tinggal, dan mendapatkan lingkungan hidup yang baik dan sehat serta berhak memperoleh pelayanan kesehatan ${ }^{1}$. Pada Pasal ini jelas bahwa kesehatan diatur dalam peraturan perundangundangan tertinggi di negara Indonesia dan menjadi dasar hukum bagi peraturan perundang-undangan di bawahnya.

Jika mencermati Undang-undang Hak Asasi Manusia yang selanjutnya disingkat menjadi HAM, Nomor 39 Tahun 1999, tersebut bahwa wanita dan anak mendapat hak khusus dalam bidang kesehatan². Undang-undang HAM Pasal 49, Pasal 62, dan Pasal 64, secara tegas menerangkan bahwa wanita dan anak mendapatkan perlakuan khusus sesuai dengan hak kelayakan yang harus diterimanya dalam bidang kesehatan.

Berdasarkan Undang-undang Nomor 36 Tahun 2009 Tentang Kesehatan, secara lebih luas dan komprehensif diamanatkan bahwa kesehatan merupakan suatu kondisi yang harus dilaksanakan oleh negara dan negara menjamin kesehatan bagi seluruh masyarakat guna tercapainya derajat kesehatan masyarakat yang setinggi-tingginya. ${ }^{3}$

Undang-undang Nomor 44 Tahun 2009 Tentang Rumah Sakit disebutkan pada Pasal 32 tentang hak pasien pada poin k, yakni memberikan persetujuan atau menolak atas tindakan yang akan dilakukan oleh tenaga kesehatan terhadap penyakit yang dideritanya; pada Pasal 37 ayat (1) Setiap tindakan kedokteran yang dilakukan di

\footnotetext{
${ }^{1}$ UUD 1945

2 UU No. 39 Tahun 1999 Tentang HAM

${ }^{3}$ UU No. 36 Tahun 2009 Tentang Kesehatan, LN No. 144
} 
Rumah Sakit harus mendapat persetujuan pasien atau keluarganya, Ayat 2 Ketentuan mengenai persetujuan tindakan kedokteran sebagaimana dimaksud pada Ayat 1 dilaksanakan sesuai dengan ketentuan peraturan perundang-undangan. ${ }^{4}$

Undang-undang Nomor 29 Tahun 2004 tentang Praktek Kedokteran pada Bab Persetujuan Tindakan Kedokteran atau Kedokteran Gigi dijelaskan bahwa Pasal 45 Ayat 1: Setiap tindakan kedokteran atau kedokteran gigi yang akan dilakukan oleh dokter atau dokter gigi terhadap pasien harus mendapat persetujuan; Ayat 2: Persetujuan sebagaimana dimaksud pada ayat (1) diberikan setelah pasien mendapat penjelasan secara lengkap; Ayat 3: Penjelasan sebagaimana dimaksud pada ayat (2) sekurang-kurangnya mencakup: a) diagnosis dan tata cara tindakan medis; b) tujuan tindakan medis yang dilakukan; c) alternatif tindakan lain dan risikonya; d) risiko dan komplikasi yang mungkin terjadi; dan e) prognosis terhadap tindakan yang dilakukan; Ayat 4: Persetujuan sebagaimana dimaksud pada ayat (2) dapat diberikan baik secara tertulis maupun lisan; Ayat 5: Setiap tindakan kedokteran atau kedokteran gigi yang mengandung risiko tinggi harus diberikan dengan persetujuan tertulis yang ditandatangani oleh yang berhak memberikan persetujuan. ${ }^{5}$ Jelas pada Pasal 45 ini adalah seluruh tindakan kedokteran dan kedokteran gigi dengan risiko tinggi harus mendapatkan persetujuan tertulis dari pasien atau keluarganya.

Perkembangan ilmu pengobatan yang dilakukan pengobat dan pasien sebagai pengguna, memiliki hubungan kepercayaan. Kepercayaan dalam hal ini adalah bahwa pengobat mampu mengobati pasien. Di jaman modern hubungan tersebut disebut perjanjian medis. Timbulnya perjanjian medis adalah karena adanya kebutuhan dari pasien untuk mencari solusi dari masalah kesehatannya. ${ }^{6}$ Dokter atau rumah sakit adalah pihak yang dapat memberi solusi dari masalah kesehatan pasien tersebut. Akibat dari hubungan tersebut adalah pasien berada dalam posisi yang lemah karena menginginkan

${ }^{4}$ UU No. 44 Tahun 2009 Tentang Rumah Sakit, LN No. 153.

${ }^{5}$ UU No. 29 Tahun 2004 Tentang Praktek Kedokteran, LN No. 4431.

${ }^{6}$ Buku III Pasal 1319 KUH Perdata 
penyakitnya disembuhkan oleh dokter, dan dokter atau rumah sakit berada di posisi yang kuat karena dianggap selalu dapat menyembuhkan penyakit pasien itu. Namun pada kenyataannya tidaklah benar jika dokter dipandang oleh pasien selalu dapat menyembuhkan penyakitnya. Dokter bekerja melalui proses sesuai dengan Standart Operating Procedure (SOP) dan ilmu pengetahuan yang dimiliki untuk membantu proses penyembuhan pasien tersebut, sedangkan pasien memandang bahwa dengan datang ke dokter ia dapat sembuh atau dengan kata lain pasien hanya peduli dengan hasilnya.

Pada saat menangani pasien yang sedang terancam nyawanya, dokter harus bertindak cepat, tepat dan bermutu untuk menolong pasien tersebut agar dapat menyelamatkan nyawa pasien dari kematian. Sebelum memberikan tindakan medis kepada pasien tersebut, berdasarkan UU No. 36 Tahun 2009 Tentang Kesehatan, UU No. 29 Tahun 2004 Tentang Praktik Kedokteran dan Permenkes No. 290/Menkes/Per/III/2008 Tentang Persetujuan Tindakan Kedokteran, dokter harus mendapatkan persetujuan medik dari pasiennya atau informed consent, karena tanpa itu dokter dapat dipersalahkan secara hukum atas tindakannya. ${ }^{7}$

Lain halnya ketika pasien pada kondisi yang tidak sadar, dimana pihak dokter mengalami dilema dalam mengambil suatu tindakan medik bagi pasiennya karena di dalam Undang-undang Praktik Kedokteran, dokter berkewajiban untuk mendapat persetujuan dalam melakukan tindakan medis dari pasien atau keluarganya, karena itu perlu dikaji lebih mendalam mengenai tindakan medik bagi pasien gawat darurat terkait dengan adanya informed consent yang wajib diberikan oleh dokter kepada pasien sebelum melakukan suatu tindakan medik, dengan mengedepankan prinsip "The health of my patient will be my first consideration" yakni kesehatan pasien merupakan hal yang harus diutamakan oleh dokter. ${ }^{8}$

Seiring dengan berkembangnya pola pikir masyarakat, sudut

7 Wijaya, 2016, Penelitian Tinjauan Yuridis Informed Concent Bagi Penanganan Pasien Gawat Darurat, FH Unud, h. 2.

8 UU No. 29 Tahun 2004 Tentang Praktik Kedokteran, LN No. 4431 
pandang tersebut bergeser dimana dokter bukan lagi berada di posisi yang superior namun sejajar dengan pasiennya, pasien dapat menentukan sendiri haknya dan metode apa yang akan digunakan untuk pengobatan penyakitnya. Masyarakat pada umumnya mengetahui bahwa tindakan medis adalah hanya berfokus pada tindakan penyembuhan atau terapeutik. Namun, tindakan medis sendiri cakupannya lebih luas dari hanya sekedar tindakan penyembuhan. Tindakan medis sesuai dengan Peraturan Menteri Kesehatan Nomor 290 Tahun 2008 Tentang Persetujuan Tindakan Kedokteran ada 4 macam ruang lingkupnya, yaitu: preventif, diagnostik, terapeutik dan rehabilitatif. ${ }^{9}$ Profesi dokter merupakan profesi yang memiliki tanggung jawab berat karena dari profesi ini digantungkan banyak harapan hidup, kesehatan dan hidup matinya seseorang maupun keluarganya. Namun dokter hanyalah manusia biasa yang menjalankan profesinya dengan pengetahuan dan kemampuannya yang tidak tak terbatas. Tiap tindakan medis yang dilakukan oleh dokter untuk menyembuhkan dan memperbaiki kondisi kesehatan pasiennya bukan tanpa resiko, keadaan ini disebut resiko medik.

Rumah sakit menurut Undang-undang No. 44 Tahun 2009 tentang Rumah Sakit, adalah merupakan institusi pelayanan kesehatan yang menyelenggarakan pelayanan kesehatan perorangan secara paripurna yang menyediakan pelayanan rawat inap, rawat jalan, dan gawat darurat yang salah satu tujuannya memberikan perlindungan terhadap keselamatan pasien, masyarakat, lingkungan rumah sakit dan sumber daya manusia di rumah sakit dengan terus meningkatkan mutu dan mempertahankan standar pelayanan rumah sakit. ${ }^{10}$

Kasus lain di ruang gawat darurat, ketika ada pasien anak mengalami patah tulang/fraktur, mendapat penanganan setelah menunggu sekitar 6 jam. Hal ini terjadi karena di ruang gawat darurat rumah sakit sangat sibuk menangani banyak pasien gawat. Ada dua kondisi yang tidak jelas secara hukum dalam hal ini, yakni ketika pasien anak yang tidak dapat memberikan pendapat tindakan medis atas Kedokteran

9 Permenkes No. 290 Tahun 2008 Tentang Persetujuan Tindakan

10 UU No. 44 Tahun 2009 Tentang Rumah Sakit, LN No. 153 
dirinya sendiri, ia perlu mendapat bantuan persetujuan tindakan medis dari keluarganya; yang kedua adalah tidak jelas apakah ketika pasien berada di ruang gawat darurat yang telah menunggu 6 jam dapat dikatakan tidak terlindungi secara hukum di rumah sakit. Apakah dokter menjadi malpraktik dalam hal ini. Kasus akan semakin pelik ketika pasien tersebut dalam keadaan trauma kepala yang menyebabkan hilangnya kesadaran pasien dan pasien yang bersangkutan sampai ke rumah sakit diantar oleh masyarakat umum bukan keluarganya.

Konsep dasar kesalahan dalam hukum pidana (schuld) begitu berbeda, dengan konsep dasar kesalahan yang ada dalam disiplin ilmu kedokteran dan etika kedokteran. ${ }^{11}$ Hal yang membedakan, dimana terletak pada sifat umum (lex generalis) kesalahan yang ada dalam hukum pidana, dan sifat khusus (lex specialis) yang terdapat dalam disiplin ilmu kedokteran dan etika kedokteran, selain itu juga kesalahan dalam hukum pidana lebih mengutamakan pada akibat dari suatu perbuatan pidana sebagai contohnya pelanggarannya.

Saat seorang pasien merasa dirugikan olen seorang dokter dalam pelayanan kedokterannya, maka pasien dapat mengadukan dokter tersebut sesuai dengan persepsinya (belum tentu dokternya yang salah), akan dituntut ke wilayah pidana, digugut ke wilayah perdata atau dilaporkan ke MKDKI atau IDI bila dianggap melakukan kesalahan prosedur atau melanggar etika, dan tidak tertutup kemungkinan dengan kesalahan atau kelalaian yang sama, seorang dokter dapat diajukan oleh pasien. ${ }^{12}$

Kesalahan tindakan medis seperti kasus di atas dapat terjadi malpraktek. Malpraktek adalah kesalahan profesi yang dilakukan oleh seorang profesional seperti dokter, dokter gigi, dokter hewan. Malpraktek bisa diakibatkan oleh kelalaian atau kurangya keterampilan dalam pelaksanaan tugas profesional; kesalahan yang disengaja atau praktik ilegal/tidak etis.

Guna menghindari terjadinya malpraktek baik malpraktek dolus dan malpraktek culpoos yang diakibatkan wanprestasi atau perbuatan 2014 , h. 53

${ }^{11}$ Buamona, Tanggung Jawab Pidana Dokter Dalam Kesalahan Medis, ${ }^{12}$ Elvandari, Hukum Penyelesaian Sengketa Medis, 2015, h. 188-190. 
melawan hukumnya dokter. Maka perlu adanya kesepakatan antara dokter dengan pasiennya (informed consent) sebelum melakukan tindakan medik. Informed conset bermula timbul karena adanya hubungan antara dokter dengan pasien melalui transaksi terapeutik yang menimbulkan hak dan kewajiban dari masing-masing pihak, baik itu pemberi pelayanan (medical providers) maupun penerima pelayanan (medical receivers) yang mengikat dan harus dihormati oleh kedua belah pihak yang terikat kontrak terapeutik tersebut ${ }^{13}$ Pengaturan tentang informed consent ini di antaranya terdapat pada Pasal 39, 45 dari UU No 29 Tahun 2004 tentang Praktek Kedokteran yang menyatakan bahwa, praktek kedokteran diselenggarakan berdasarkan pada kesepakatan antara dokter dengan pasien dalam upaya untuk pemeliharaan kesehatan, pencegahan penyakit, peningkatan kesehatan, pengobatan penyakit dan pemulihan kesehatan.

Adanya Informed Consent pasien dapat dilindungi dari kesewenang-wenangan dokter. Malpraktek merupakan akibat dari wanprestasi atau perbuatan melawan hukum, alasannya adalah karena malpraktek terjadi bisa karena dokter itu tidak melakukan tindakan sesuai apa yang telah diperjanjikan dengan pasien atau dokter tersebut melakukan tindakan yang dilarang oleh hukum. Informed Consent dapat memberi pasien informasi tentang apa saja tindakan medis yang akan dilakukan dalam penyembuhan penyakitnya sekaligus memberi perlindungan terhadap kemungkinan terjadinya malpraktek medis.

Tanggung jawab hukum dokter adalah suatu keterikatan dokter terhadap ketentuan-ketentuan hukum dalam menjalankan profesinya. Tanggung jawab dokter dalam bidang hukum terbagi tiga bagian, yaitu tanggung jawab hukum dokter dalam bidang hukum perdata, pidana, dan administrasi. ${ }^{14}$ Tanggung jawab inilah yang membuat seorang dokter harus benar-benar melakukan pelayanan kesehatan sesuai dengan profesi dan standar pelayanan kedokteran.

Berdasarkan rumusan permasalahan yang telah dirumuskan dalam pertanyaan penelitian, dapat dikemukakan tujuan penelitian adalah: untuk mengetahui aturan hukum informed consent di Indonesia

\footnotetext{
${ }^{13}$ Muntaha, 2017, Hukum Pidana Malapraktik, Jakarta, h. 23.

${ }^{14}$ Sadi, 2015, Etika Hukum Kesehatan, Jakarta, h. 103.
} 
yang dapat memberikan perlindungan hukum bagi dokter dan pasien dan untuk mengeksplorasi sanksi hukum yang dapat diberikan apabila terjadi malpraktek dokter terkait dengan informed consent yang berakibat fatal bagi kesehatan pasien.

\section{TINJAUAN PUSTAKA}

Rumusan masalah 1 adalah bagaimana aturan hukum Informed Consent di Indonesia dapat memberi perlindungan hukum bagi dokter dan pasien. Teori hukum yang digunakan adalah sebagai berikut:

\section{Teori Gustav Radburch - kepastian Hukum}

Gustav Radburch menyebut bahwa hukum memiliki 3 aspek, yakni: keadilan, finalitas, dan kepastian. Aspek keadilan menunjuk pada kesamaan hak di depan hukum. Aspek finalitas, menunjuk pada tujuan keadilan, yaitu memajukan kebaikan dalam hidup manusia. Aspek ini menentukan isi hukum. Sedangkan kepastian menunjuk pada jaminan bahwa hukum (yang berisi keadilan dan norma-norma yang memajukan kebaikan), benar-benar berfungsi sebagai peraturan yang ditaati. $^{15}$

Konsep kepastian hukum berpendapat menegakkan hukum sama artinya dengan menegakkan undang-undang. Pendapat ini dipengaruhi oleh pandangan bahwa hukum tidak lain dari rangkaian norma-norma positif dalam sistem perundang-undangan. Pandangan tentang hukum yang demikian itu, menurut Satjipto Rahardjo menjadi bersifat optik perskriptif, yaitu memandang hukum hanya sebagai sistem kaidah yang penganalisisnya terlepas dari landasan kemasyarakatannya. Ilmu hukum hanya dipandang sebagai sebuah norma untuk menghasilkan pola problem solving yang hanya menciptakan kemahiran sebagai ahli-ahli hukum yang mahir menafsirkan dan menerapkan hukum positif.

Masyarakat mengharapkan ada kepastian hukum, karena dengan ada kepastian hukum masyarakat akan lebih

15 Tanya, Bernard, Simanjuntak Yoan, Hage Markus, 2013, Teori Hukum, Strategi Tertib Manusia Lintas Ruang dan Generasi, Yogyakarta, h.118. 
tertib. Hukum bertugas menciptakan kepastian hukum karena bertujuan ketertiban hukum.

\section{Teori John Locke - Perlindungan Hukum}

John Locke sebagai penganut hukum alam abad ke-18 berpegang pada prinsip hukum alam zaman itu, yakni kebebasan individu dan keutamaan rasio. Locke mengajarkan tentang kontrak sosial. Orang-orang yang melakukan kontrak sosial, bukanlah orang yang ketakutan dan pasrah, tetapi orangorang yang tertib yang elan dan menghargai kebebasan, hak hidup, dan kepemilikan harta sebagai hak bawaan sebagai manusia. Hak-hak tersebut tidak ikut diserahkan kepada penguasa ketika kontrak sosial dilakukan. Oleh karena itu, kekuasaan penguasa yang diberikan lewat kontrak sosial, dengan sendirinya tidak mungkin bersifat mutlak. Adanya kekuasaan tersebut justru untuk melindungi hak-hak kodrat dimaksud dari bahaya-bahaya yang mungkin mengancam, baik yang datang dari dalam maupun dari luar. Memastikan hukum yang dibuat itu memang diarahkan pada perlindungan hak-hak dasar tersebut. Rakyat sendirilah yang harus menjadi pembuat hukum. ${ }^{16}$

John Locke adalah seorang filsuf dari Inggris yang menjadi salah satu tokoh utama dari pendekatan empirisme. Selain itu, di dalam bidang filsafat politik, Locke juga dikenal sebagai filsuf negara liberal. Locke menandai lahirnya era Modern dan juga era pasca-Descartes (post-Cartesian), karena pendekatan Descartes tidak lagi menjadi satu-satunya pendekatan yang dominan di dalam pendekatan filsafat waktu itu. Kemudian Locke juga menekankan pentingnya pendekatan empiris dan juga pentingnya sejumlah eksperimen di dalam mengembangkan ilmu pengetahuan.

\section{Teori Aristoteles - Sosial Etik}

Aristoteles mengaitkan teorinya tentang hukum dengan perasaan sosial-etis. Perasaan tersebut bukanlah bawaan

${ }^{16}$ Tanya, Bernard, Simanjuntak Yoan, Hage Markus, 2013, Teori Hukum, Strategi Tertib Manusia Lintas Ruang dan Generasi, Yogyakarta, h. 66-67. 
alamiah manusia sempurna, bukan pula mutu kaum terpilih (aristokrat). Perasaan sosial-etis justru ada dalam konteks individu sebagai warga negara (polis). Hukum seperti halnya polis, merupakan wahana yang diperlukan untuk mengarahkan manusia pada nilai-nilai moral yang rasional. Hanya dalam polis yang merupakan institusi logos (teratur, rasional, bermoral, dan mencerahkan) seorang individu dimungkinkan menjadi mahkluk moral yang rasional. Dengan meraih keadaanini, manusia dapat menikmati kebahagiaan (eudaimonia). Inti manusia moral yang rasional adalah memandang kebenaran (theoria, kontemplasi) sebagai keutamaan hidup (summum bonum). Dalam rangka ini, manusia dipandu dua pemandu, yakni: akal dan moral. ${ }^{17}$

Rumusan masalah 2 adalah apa sanksi hukum yang dapat diberikan apabila terjadi malpraktek dokter terkait dengan Informed Consent yang berakibat fatal bagi kesehatan pasien. Teori hukum yang digunakan adalah sebagai berikut:

\section{Teori Gustav Radburch - Keadilan Normatif}

Gustav Radbruch mematrikan nilai keadilan sebagai mahkota dari setiap tata hukum. Radbruch memandang Sein dan Sollen, materi dan bentuk sebagai dua sisi dari satu mata uang. Materi mengisi bentuk dan bentuk melindungi materi. Hal ini adalah frase yang tepat untuk melukiskan tentang hukum dan keadilan. Nilai keadilan adalah mteri yang harus menjadi isi aturan hukum. Sedangkan aturan hukum adalah bentuk yang harus melindungi nilai keadilan. Hukum sebagai pengemban nilai keadilan menjadi ukuran bagi adil tidak adilnya tata hukum. Nilai keadilan juga menjadi dasar dari hukum sebagai hukum. Dengan demikian, keadilan memiliki sifat normatif sekaligus konstitusif bagi hukum. Normatif karena berfungsi sebagai prasyarat trasendental yang mendasari tiap hukum positif yang bermartabat. Menjadi landasan moral hukum dan sekaligus tolok ukur sistem hukum positif. Keadilan-lah, hukum positif berpangkal. Sedangkan konstotutif, karena keadilan harus menjadi unsur mutlak bagi hukum sebagai

17 Tanya, Bernard, Simanjuntak Yoan, Hage Markus, 2013, Teori Hukum, Strategi Tertib Manusia Lintas Ruang dan Generasi, Yogyakarta, h. 41 
hukum. Tanpa keadilan, sebuah aturan tidak pantas menjadi hukum. ${ }^{18}$

Sejalan dengan teori keadilan oleh Gustav Radvurch, pelaksanaan hukum atau praktek hukum di Indonesia dalam situasi tidak menentu, tidak hanya terletak pada aparat penegak hukum, tetapi juga karena diakibatkan oleh kerancuan opini publik dalam mengartikan atau mendefenisikan pengertian 3 substansi hukum yakni keadilan, kemanfaatan, serta kepastian hukum.

Gustav Radbuch berorientasi untuk menciptakan harmonisasi pelaksanaan hukum. Dalam prakteknya terkadang masyarakat tidak merasa puas dan bahkan menganggap bahwa hukum di Indonesia tidak membawa keadilan bagi masyarakatnya dan lebih ironisnya lagi menganggap bahwa hukum tersebut hanyalah berpihak pada golongan tetentu yang tentunya unggul dalam berbagai aspek, seperti aspek ekonomi, politik, dan lain sebagainya. Kondisi ini menunjukkan bahwa ternyata praktek hukum di Negeri ini belum memberikan kepuasaan terhadap masyarakatnya atau yang menjadi obyek hukum itu sendiri yang memang sangat kontradiksi dengan tujuan hukum yang ideal. Keadilan itu terkait dengan pendistribusian yang merata antara hak dan kewajiban. Demikian sentral dan dominan kedudukan dan peranan dari nilai keadilan bagi hukum, sehingga Gustav Radbruch menyatakan rechct ist wille zur gerechtigkeit (hukum adalah kehendak demi untuk keadilan).

Kerangka konsep penelitian ini dapat digambarkan sebagai berikut:

18 Tanya, Bernard, Simanjuntak Yoan, Hage Markus, 2013, Teori Hukum, Strategi Tertib Manusia Lintas Ruang dan Generasi, Yogyakarta, h. 116-117. 


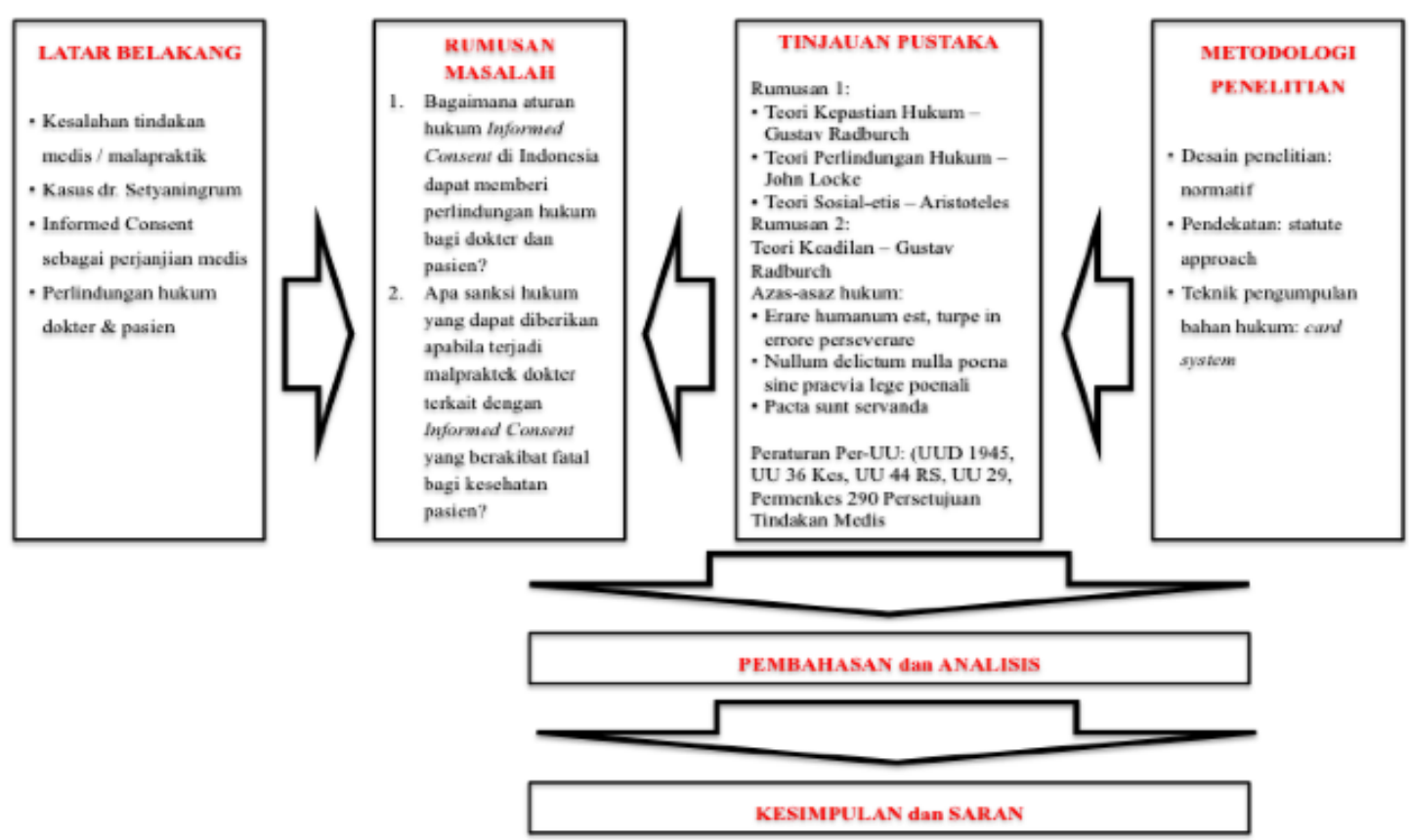

\section{METODE PENELITIAN}

Metode penelitian yang digunakan dalam penelitian ini adalah penelitian hukum normatif, yaitu penelitian hukum doktriner. Penelitian hukum normatif juga disebut sebagai penelitian perpustakaan atau studi dokumen. Disebut penelitian hukum doktriner karena penelitian ini dilakukan atau ditujukan hanya pada peraturan-peraturan yang tertulis atau bahan-bahan hukum. Penelitian ini difokuskan untuk mengkaji penerapan kaidah-kaidah atau norma-norma dalam hukum positif.

Penelitian ini menggunakan pendekatan perundang-undangan (statute approach). Dalam pendekatan ini, peneliti perlu memahami hierarki, dan asas-asas dalam peraturan perundang-undangan. Peraturan perudang-undangan ini adalah peraturan tertulis yang memuat norma hukum yang mengikat secara umum dan dibentuk atau ditetapkan oleh lembaga negara atau pejabat yang berwenang melalui perosedur yang ditetapkan dalam peraturan perundang-undangan. ${ }^{19}$

Teknik pengumpulan bahan hukum dalam proposal penelitian ini adalah menggunakan teknik sistem kartu (card system), yaitu: menelaah peraturan-peraturan yang relevan, buku-buku atau literatur, karya ilmiah atau jurnal para ahli hukum dan hasilnya dicatat dengan sistem kartu. Penggunaan sistem kartu ini adalah untuk mempermudah dalam telaah penguraian, menganalisis, dan membuat kesimpulan dari

${ }^{19}$ Marzuki, 2016, Penelitian Hukum, Surabaya, h. 137. 
kerangka pemikiran yang telah ditetapkan.

Tahapan pengumpulan data berbasis bahan hukum dengan sistem kartu lengkap, dilanjutkan dengan proses analisis hukum menggunakan pisau analisis teori hukum yang tepat. Tahapan meliputi: deskripsi (memaparkan), interprestasi (penafsiran), evaluasi, argumentasi, dan sistematisasi.

Dalam penelitian ini, jenis data adalah berupa bahan hukum. Bahan hukum bersumber primer dan sekunder. Bahan hukum primer adalah semua aturan tertulis yang ditegakkan oleh negara, semua itu bisa ditemukan dalam putusan pengadilan yang telah berkekuatan hukum tetap, undang-undang yang ditetapkan parlemen, keputusan dan peraturan eksekutif, dan putusan hukum agen-agen administrasi. ${ }^{20}$

Dalam proposal ini dilakukan prelimenary research, yakni kegiatan untuk mengumpulkan data berupa bahan hukum, terutama bahan hukum primer untuk menemukan permasalahan hukum normatif.

Bahan hukum yang relevan dikumpulkan menggunakan teknik sistem kartu (card system), yaitu menelaah peraturan-peraturan yang relevan, buku-buku atau literatur, karya ilmiah atau jurnal para ahli hukum dan hasilnya dicatat dengan sistem kartu. Penggunaan sistem kartu ini adalah untuk mempermudah dalam telaah penguraian, menganalisis, dan membuat kesimpulan dari kerangka pemikiran yang telah ditetapkan. Di dalam penelaahan melalui penguraian dan penganalisisan, adalah studi kepustakaan, yang bertujuan untuk mencapai konsepsi-konsepsi, teori-teori, pendapat-pendapat ataupun temuan-temuan yang berhubugnan erat dengan permasalahan yang sedang diteliti dalam proposal penelitian ini.

\section{HASIL PENELITIAN DAN PEMBAHASAN}

Pada bab ini diuraikan tentang hasil penelitian dan pembahasan. Sub bab pertama adalah hasil penelitian. Hasil penelitian diperoleh dari bahan hukum yang relevan. Bahan hukum ini dikumpulkan dengan menggunakan teknik sistem kartu (card system). Penggunaan sistem kartu ini adalah untuk mempermudah

20 Pasek Diantha, 2017, Metodologi Penelitian Hukum Normatif dan Justifikasi Teori Hukum, Denpasar, h. 142. 
dalam telaah penguraian, menganalisis, dan membuat kesimpulan dari kerangka pemikiran yang telah ditetapkan. Setelah dilakukan analisis dengan sistem kartu, dilakukan proses komputerisasi kartu. Komputerisasi kartu ini adalah menterjemahkan kartu-kartu yang berisi telaah bahan hukum ke dalam sistem komputer. Tujuan komputerisasi kartu ini adalah untuk mempermudah penyimpanan hasil penelitian deskriptif dan mempermudah proses analisis serta pembahasan selanjutnya.

Penelitian ini mengeksplorasi bahan hukum berupa peraturan perundang-undangan yaitu: Undang-undang Nomor 39 Tahun 1999 tentang Hak Asasi Manusia, Undang-undang Nomor 29 Tahun 2004 tentang Praktik Kedokteran, Undang-undang Nomor 36 Tahun 2009 tentang Kesehatan, Undang-undang Nomor 44 Tahun 2009 tentang Rumah Sakit, Undang-undang Nomor 36 Tahun 2014 tentang Tenaga Kesehatan, dan Peraturan Menteri Kesehatan Nomor 290/Menkes/Per/III/2008 tentang Persetujuan Tindakan Kedokteran.

\section{Pembahasan Hukum Perdata Informed Consent}

Menurut hukum perdata, hubungan profesional antara dokter dengan pasien dapat terjadi karena 2 hal, yaitu:

a. Berdasarkan perikatan dalam perjanjian (ius contractu) yang berbentuk kontrak terapeutik secara sukarela antara dokter dengan pasien berdasarkan kehendak bebas. Tuntutan dapat dilakukan bila terjadi "wanprestasi", yakni pengingkaran terhadap hal yang diperjanjikan. Dasar tuntutan adalah tidak, terlambat, salah melakukan, ataupun melakukan sesuatu yang tidak boleh dilakukan menurut perjanjian itu. iscep:

b. Berdasarkan hukum (ius delicto), berlaku prinsip siapa merugikan orang lain harus memberikan ganti kerugian.

Rumusan perjanjian/kontrak menurut hukum perdata merupakan suatu tindakan/perbuatan hukum yang dilakukan secara sukarela oleh dua orang atau lebih, yang bersepakat untuk memberikan "prestasi" satu kepada lainnya. Dalam hubungan antara dokter dengan pasien, timbul perikatan usaha (inspanningsverbintenis) dimana sang dokter berjanji memberikan 
"prestasi" berupa usaha penyembuhan yang sebaik-baiknya dan pasien selain melakukan pembayaran, ia juga wajib memberikan informasi secara benar atau mematuhi nasihat dokter sebagai "kontra-prestasi". Disebut perikatan usaha karena didasarkan atas kewajiban untuk berusaha. Dokter harus berusaha dengan segala daya agar usahanya dapat menyembuhkan penyakit pasien. Hal ini berbeda dengan kewajiban yang didasarkan karena hasil/resultaat pada perikatan hasil (resultaatverbintenis), dimana prestasi yang diberikan dokter tidak diukur dengan apa yang telah dihasilkannya, melainkan ia harus mengerahkan segala kemampuannya bagi pasien dengan penuh perhatian sesuai standar profesi medis. Selanjutnya dari hubungan hukum yang terjadi ini timbullah hak dan kewajiban bagi pasien dan dokter sesuai dengan perannya masing-masing.

Hubungan dokter dengan pasien yang meminta pengobatan atau konsultasi dan kemudian diterima oleh dokter itu, maka terjadilah suatu persetujuan untuk melakukan beberapa jasa (overeenkomst tot het verrichten van enkele diensten). Persetujuan terapeutik ini di dalam hukum perdata termasuk inspanningverbintenis yang artinya suatu persetujuan di mana satu pihak berjanji untuk berusaha semaksimal. (Jurnal Tempo Medical Record dan Informed Consent, 8 Oktober 1988, hal. D2)

\section{Pembahasan Hukum Pidana Informed Consent}

Persetujuan tindakan kedokteran dari segi hukum pidana harus menganut asas legalitas. Asas legalitas (the principle of legality) ini adalah asas yang menentukan bahwa tiap-tiap peristiwa pidana (delik/tindak pidana) harus diatur terlebih dahulu oleh suatu aturan undang-undang sebelum orang itu melakukan tindakan kedokteran. Berlakunya asas legalitas memberikan sifat perlindungan hukum bagi pasien maupun dokter terhadap pelaksanaan tindakan kedokteran.

Anselm von Feuerbach, ahli hukum pidana Jerman, menyatakan asas legalitas dalam bahasa Latin, yaitu: Nulla poena sine lege: tidak ada pidana tanpa ketentuan pidana menurut undangundang, Nulla poena sine crimine: tidak ada pidana tanpa perbuatan pidana. isepis Nullum crimen sine poena legali: tidak ada perbuatan 
pidana tanpa pidana menurut undang-undang. is dirangkum dalam satu kalimat, yaitu nullum delictum, nulla poena sine praevia lege poenali. Artinya, tidak ada perbuatan pidana, tidak ada pidana, tanpa ketentuan undang-undang terlebih dahulu. Asas legalitas diadakan bertujuan untuk: memperkuat adanya kepastian hukum. Informed consent sebagai aspek legal atas tindakan kedokteran dapat menimbulkan dampak pidana jika terjadi malpraktek.

\section{Pembahasan Administratif Informed Consent}

Perjanjian adalah dasar dari perikatan, perjanjian menerbitkan perikatan. Suatu perjanjian juga dinamakan persetujuan karena dua pihak (pasien dan dokter) yang bersangkutan setuju untuk melakukan sesuatu. Jadi dapat dikatakan bahwa dua perikatan (perjanjian dan persetujuan) mempunyai arti yang sama. Istilah kontrak memiliki arti yang lebih sempit, karena kontrak merujuk pada perjanjian yang tertulis.

Keterikatan antara pasien dengan dokter merupakan hubungan yang erat dan kompleks keeratan hubungan antara pasien karena diharuskan adanya kesalingpercayaan dan keterbukaan. Dalam hukum pasien dan dokter masing-masing memiliki hak dan kewajiban.

Berdasarkan Undang-undang Nomor 29 tahun 2004 tentang Praktik Kedokteran Pasal 52, dalam menerima pelayanan pada praktik kedokteran, pasien mempunyai hak yaitu: mendapatkan penjelasan secara lengkap tentang tindakan medis, meminta pendapat dokter, mendapat pelayanan sesuai dengan kebutuhan medis, menolak tindakan medis, dan mendapat isi rekam medik.

Berdasarkan uraian panjang sistem kartu peraturan perundangundangan di atas, dapat dirangkum pembahasan sebagai berikut:

1. Secara umum dapat disampaikan bahwa telah ada peraturan perundang-undangan yang mengatur tentang persetujuan tindakan kedokteran/informed consent, namun belum secara detail mampu mengakomodir perlindungan hukum bagi pasien maupun dokter/dokter gigi. 
2. Semua tindakan kedokteran harus mendapat persetujuan pasien/keluarga terdekat mengenai tindakan kedokteran/kedokteran gigi yang akan dilakukan oleh dokter/dokter gigi.

3. Arti keluarga terdekat dalam hal ini adalah suami atau istri, ayah atau ibu kandung, anak-anak kandung, saudara-saudara kandung atau pengampunya. Makna dari pengampu pasien tidak jelas dalam hal ini.

4. Adanya aturan definisi pasien yang kompeten, yakni pasien dewasa atau bukan anak menurut peraturan perundang-undangan atau telah/pernah menikah, tidak terganggu kesadaran fisiknya, mampu berkomunikasi secara wajar, tidak mengalami kemunduran perkembangan (retardasi) mental dan tidak mengalami penyakit mental sehingga mampu berbuat keputusan secara bebas. Dalam hal pasien adalah anak-anak atau orang yang tidak sadar, penjelasan diberikan kepada keluarganya atau yang mengantar. Semakin tidak jelas makna orang yang mengantar pasien anak-anak. Tanggung jawab dan tanggung gugat tidak jelas.

5. Adanya dualisme bahwa persetujuan tindakan kedokteran dapat diberikan secara tertulis maupun lisan.

6. Setiap tindakan kedokteran yang mengandung risiko tinggi harus memperoleh persetujuan tertulis yang ditandatangani oleh yang berhak memberikan persetujuan. Kata berhak dalam hal ini dapat bermakna pasien/keluarganya; dapat pula tidak jelas maknanya.

7. Ada aturan bahwa dalam keadaan gawat darurat, untuk menyelamatkan jiwa pasien dan/atau mencegah kecacatan tidak diperlukan persetujuan tindakan kedokteran. Cenderung melemahkan salah satu pihak bila terjadi kejadian yang tidak diinginkan atas kondisi pasien pasca tindakan kedokteran.

8. Persetujuan tindakan kedokteran dapat dibatalkan/ditarik kembali secara tertulis oleh yang memberi persetujuan sebelum dimulainya tindakan. Tindakan kedokteran juga dapat ditolak oleh pasien/keluarganya secara tertulis dan menjadi tanggung jawab pasien. 
9. Secara tegas diatur bahwa pemberian persetujuan tindakan kedokteran tidak menghapuskan tanggung gugat hukum dalam hal terbukti adanya kelalaian dalam melakukan tindakan kedokteran yang mengakibatkan kerugian pada pasien.

10. Ada aturan bahwa jika terdapat indikasi kemungkinan perluasan tindakan kedokteran, dokter yang akan melakukan tindakan juga harus memberikan penjelasan. Perluasan tindakan kedokteran yang tidak terdapat indikasi sebelumnya, hanya dapat dilakukan untuk menyelamatkan jiwa pasien.

11. Ada suatu kondisi super power dari pemerintah, bahwa dalam hal tindakan kedokteran harus dilaksanakan sesuai dengan program pemerintah dimana tindakan medik tersebut untuk kepentingan masyarakat banyak, maka persetujuan tindakan kedokteran tidak diperlukan.

12. Pelaksanaan tindakan kedokteran yang telah mendapat persetujuan menjadi tanggung jawab dokter atau dokter gigi yang melakukan tindakan kedokteran. Sarana pelayanan kesehatan bertanggung jawab atas pelaksanaan persetujuan tindakan kedokteran. Pihak rumah sakit atau sarana pelayanan kesehatan lainnya menjadi pihak yang juga ikut bertanggung jawab, namun tidak jelas seperti apa.

13. Informed consent merupakan perikatan antara pasien dengan dokter/dokter gigi yang mana pasien telah menyetujui tindakan kedokteran/kedokteran gigi yang diatur dalam hukum perdata.

14. Perikatan pasien dan dokter dalam informed consent yang menimbulkan kerugian bagi pasien yang bersangkutan, dapat dilakukan penggantian biaya dan kerugiannya.

15. Hakim dapat menghapuskan segala tuntutan pertentangan akibat perikatan antara pasien dan dokter.

16. Perikatan antara pasien (usia anak, orang dengan pengampuan dan perempuan tertentu berdasarkan undang-undang) dengan dokter, tidak cakap menyetujui informed consent, menyebabkan tidak dapat menyetujui tindakan kedokteran.

17. Perikatan antara pasien dan dokter dilakukan dengan itikat baik. 
18. Perikatan juga dapat timbul akibat adanya undang-undang yang mengatur, yaitu perikatan antara pasien dan dokter dalam tindakan kedokteran berdasar Undang-undang Praktik Kedokteran.

19. Berdasarkan informed consent dapat dipidanakan apabila memenuhi unsur pidana. Pasien dapat menuntut pidana dokter yang diduga lalai/alpa menyebabkan kondisi lebih buruk pasien yang bersangkutan.

20. Dokter sesuai aturan pidana, hanya dapat diproses secara hukum apabila ada pengaduan dari pasien/keluarga yang dikenai tindakan kedokteran.

21. Tindakan kedokteran yang dilakukan oleh dokter kepada pasien dapat menimbulkan luka berat pada pasien dan dapat disanksi pidana.

22. Dokter yang dengan sengaja membiarkan pasien dalam keadaan sengsara dapat dikenai sanksi pidana.

23. Tindakan kedokteran yang dilakukan oleh dokter kepada pasiennya, terjadi kematian akibat kealpaannya atau malpraktik, dapat dikenaik sanksi pidana.

24. Pelaksanaan informed consent, apabila dokter tidak melakukan tindakan kedokteran sesuai dengan persetujuan yang telah disetujui oleh pasien, dan menyebabkan meninggalnya pasien, maka dokter tersebut akan dikenai sanksi pidana atau pidana denda. 


\section{KESIMPULAN}

Berdasarkan hasil analisis bahan hukum dan pembahasan dalam penelitian ini dapat direkomendasikan sebagai berikut:

1. Perlindungan hukum bagi pasien dan dokter telah ada peraturan perundang-undangan yang mengaturnya, namun belum sepenuhnya dapat mengakomodir semua kebutuhan aspek perlindungan hukum.

2. Perlindungan hukum bagi dokter jika ada tindakan kedokteran yang berisiko tinggi dengan menggunakan informed consent tertulis dari pasien/keluarganya.

3. Pembatalan informed consent oleh pasien secara tertulis akan memberi perlindungan hukum bagi dokter.

4. Program pemerintah yang bersifat nasional dan tidak membutuhkan informed conset, memposisikan masyarakat (pasien) di posisi lemah jika terjadi kejadian yang tidak diharapkan setelah mendapat tindakan kedokteran.

5. Pengampun dan pengantar pasien dapat memberikan persetujuan tindakan kedokteran. Hal ini sangat tidak jelas aspek hukumnya karena ketidakjelasan siapa yang disebut dengan pengampu dan pengantar pasien untuk pasien anak-anak, tidak memiliki kekuatan hukum terhadap pasien anak.

6. Kegawatdaruratan memerlukan tindakan kedokteran tanpa persetujuan dari pasien/keluarganya. Hal ini menjadikan posisi dokter dan pasien berada pada timbangan yang sama. Kegawatdaruratan menimbulkan perikatan akibat adanya undangundang yang mengatur, yaitu tindakan kedokteran berdasar Undang-undang Praktik Kedokteran.

7. Perlindungan hukum bagi pasien sangat tinggi ketika walau telah ada persetujuan tindakan kedokteran namun, dokter/dokter gigi dapat digugat bila terdapat masalah/kerugian bagi pasien akibat kelalaian.

8. Pembatalan informed consent oleh pasien secara tertulis dan menjadi tanggung jawab pasien bila terjadi keadaan yang merugikan pasien dari sisi keselamatan dan kesehatan pasien. 
Dalam hal ini pasien tidak mendapatkan perlindungan hukum yang pasti.

9. Pihak sarana pelayanan tempat tindakan kedokteran dilakukan juga memiliki tanggung jawab atas pelaksanaan tindakan kedokteran ini. Hal ini tidak menguntungkan bagi pemilik sarana pelayanan seperti rumah sakit jika ada kejadian yang tidak diharapkan terjadi.

10. Perikatan pasien dan dokter dalam informed consent yang menimbulkan kerugian bagi pasien yang bersangkutan, dapat dilakukan penggantian biaya dan kerugiannya.

11. Perikatan antara pasien dan dokter dilakukan dengan itikat baik.

12. Seorang dokter/dokter gigi dapat dipidanakan oleh pasien atas tindakan kedokteran/kedokteran gigi yang menimbulkan kondisi pasien yang bersangkutan lebih buruk atau luka berat, dengan adanya pengaduan dari pasien/keluarganya.

13. Tindakan kedokteran yang dilakukan oleh dokter kepada pasiennya, terjadi kematian akibat kealpaannya atau malpraktik, dapat dikenai sanksi pidana.

14. Pelaksanaan informed consent, apabila dokter tidak melakukan tindakan kedokteran sesuai dengan persetujuan yang telah disetujui oleh pasien, dan menyebabkan meninggalnya pasien, maka dokter tersebut akan dikenai sanksi pidana atau pidana denda.

\section{DAFTAR PUSTAKA}

\section{Buku:}

Astuti, 2013, Hubungan Hukum Antara Dokter dengan Pasien Dalam Upaya Pelayanan Medis, Jakarta.

Asyhadie, Z.,2017, Aspek-aspek Hukum Kesehatan di Indonesia, Rajawali Pers,Depok.

Buamona, H.,2014, Tanggung Jawab Pidana Dokter Dalam Kesalahan

Medis. Parama Publishing, Yogyakarta,

Buamona, H.,2016, Medical Record and Informed Consent Sebagai Alat

Bukti Dalam Pembuktian, : Parama Publishing,Yogyakarta.

Elvandari, S.,2015, Hukum Penyelesaian Sengketa Medis, Thafa 
Media,Yogyakarta.

Hadjon, P., and Djatmiati, T.S.,2016, Argumentasi Hukum, Gadjah Mada University Press, Yogyakarta.

Marpaung, L.,2012, Asas - Teori - Praktik Hukum Pidana, Sinar Grafika Jakarta.

Marzuki, P.M.,2016, Penelitian Hukum. PT. Kharisma Putra Utama,Jakarta. Muntaha,2017, Hukum Pidana Malapraktik, Sinar Grafika,Jakarta.

Sadi, M.,2015, Etika Hukum Kesehatan, Teori dan Aplikasinya di Indonesia, Predanamedia, Jakarta.

Siswati, S.,2017, Etika dan Hukum Kesehatan, Rajawali Pers,Depok.

\section{Peraturan Perundang-Undangan:}

Kitab Undang-Undang Hukum Perdata.

Kitab Undang-Undang Hukum Pidana.

Undang-undang Republik Indonesia Nomor 29 Tahun 2004 tentang Praktik Kedokteran, Tambahan Lembaran Negara Republik Indonesia Nomor 4431.

Undang-Undang Republik Indonesia Nomor 36 Tahun 2009 tentang Kesehatan, Lembaran Negara Republik Indonesia Tahun 2009 Nomor 144.

Undang-Undang Republik Indonesia Nomor 36 Tahun 2014 tentang Tenaga Kesehatan, Lembaran Negara Republik Indonesia Tahun 2014 Nomor 298.

Undang-Undang Republik Indonesia Nomor 44 Tahun 2009 tentang Rumah Sakit, Lembaran Negara Republik Indonesia Nomor 153.

Peraturan Menteri Kesehatan Nomor 290 Tahun 2008 Tentang Persetujuan Tindakan Kedokteran. 